\title{
MENINGKATKAN PRESTASI BELAJAR BAHASA INDONESIA MELALUI BIMBINGAN KONSELING
}

\author{
Ni Made Supariati \\ SMP Negeri 2 Kerambitan \\ e-mail: nimadesupariati123@gmail.com.
}

\begin{abstract}
Abstrak
Penelitian ini bertujuan untuk meningkatkan prestasi belajar Bahasa Indonesia siswa di SMP Negeri 2 Kerambitan. Kajiannya dilatarbelakangi oleh tinggi rendahnya prestasi belajar Bahasa Indonesia di sekolah. Datanya diperoleh menunjukkan prestasi belajar Bahasa Indonesia siswa adalah $45 \%$ dari 24 siswa yang memperoleh nilai sesuai dengan KKM. Sehingga perlu adanya Bimbingan Konseling dalam meningkatkan Prestasi belajar Bahasa Indonesia tersebut. Setalah dilakukan Bimbingan Konseling pada siswa kelas VIII A Semester I Tahun Pelajaran 2017/2018 di SMP Negeri 2 Kerambitan terjadi peningkatan yang signifikan, yakni pada siklus I meningkat menjadi $63 \%$ dengan rata-rata 74 sedangkan pada siklus II menjadi $90 \%$ dengan rata-rata 81 . Hal ini menunjukkan bahwa Bimbingan Konseling dapat meningkatkan Prestasi Belajar Bahasa Indonesia Siswa Kelas VIII A Semester I Tahun Pelajaran 2017/2018 SMP Negeri 2 Kerambiatan.
\end{abstract}

Kata kunci: bimbingan konseling, prestasi belajar Bahasa Indonesia.

\begin{abstract}
This study aims to improve the learning achievement of Indonesian students in SMP Negeri 2 Kerambitan. His study was motivated by the high and low achievement of learning Indonesian at school. The data obtained shows that Indonesian students' learning achievement is $45 \%$ of the 24 students who score according to KKM. So the need for counseling guidance in improving the achievement of learning Indonesian. After Counseling Guidance was conducted for students of class VIII A Semester I of the Academic Year 2017/2018 in SMP Negeri 2 Kerambitan there was a significant increase, namely in the first cycle increased to $63 \%$ with an average of 74 while in the second cycle to $90 \%$ with an average 81 . This shows that Counseling Guidance can improve Indonesian Language Learning Achievement for Class VIII A Students in Semester I Academic Year 2017/2018 of SMP Negeri 2 Kerambiatan.
\end{abstract}

Keywords : counseling guidance, Indonesian learning achievement. 


\section{Pendahuluan}

Bimbingan merupakan proses pemberian bantuan yang terus menerus dari seorang pembimbing yang telah dipersiapkan kepada individu yang membutuhkannya dalam rangka mengembangkan seluruh potensi yang dimilikinya secara optimal dengan menggunakan berbagai macam media dan teknik bimbingan dalam suasana asuhan yang normatif agar tercapai kemandirian sehingga individu dapat bermanfaat baik bagi dirinya sendiri maupun bagi lingkungannya. Konseling merupakan salah satu teknik dalam pelayanan bimbingan dimana proses pemberian bantuan itu berlangsung melalui wawancara dalam serangkaian pertemuan langsung dan tatap muka antara guru pembimbing / konselor dengan klien dengan tujuan agar klien itu mampu memperoleh pemahaman yang lebih baik terhadap dirinya, mampu memecahkan masalah yang dihadapinya dan mampu mengarahkan dirinya untuk mengembangkan potensi yang dimiliki ke arah perkembangan Sofyan S. Willis, Konseling Individual Teori dan Praktek, (Bandung: Alfabeta, 2007), hlm. 13 yang optimal, sehingga ia dapat mencapai kebahagiaan pribadi dan kemanfaatan sosial. Bimbingan dan konseling di sekolah merupakan suatu disiplin ilmu yang secara professional memberikan pelayanan bimbingan kepada peserta didik. Dengan pelayanan yang baik akan tercipta suatu iklim yang kondusif serta menciptakan masyarakat yang berakhlak dan bermoral. Di sekolah, kegiatan bimbingan dan konseling diselenggarakan oleh pejabat fungsional yang secara resmi dinamakan guru pembimbing. Bimbingan dan konseling di sekolah selain meminimalisir angka kenakalan murid juga mempunyai peran vital dalam meningkatkan kualitas anak didik.3 Bimbingan dan konseling tidak hanya merupakan cara yang secara psikologis sangat efektif dalam membantu seseorang mencapai dan mempertahankan hubungan dengan realistis, yakni melalui pekerjaan yang bermakna dan produktif, tetapi juga menyiapkan sarana ekonomi untuk mempengaruhi perubahan sosial, misalnya melalui perluasan atau pelebaran rentang pilihan-pilihan bagi kaum wanita.4 Layanan bimbingan dan konseling akan optimal jika difokuskan pada perkembangan pribadi, sosial dan pemecahan

Mengacu pada pemahaman di atas peneliti selaku guru BK di SMP Negeri 2 Kerambiatan memutuskan untuk meningkatkan prestasi belajar siswa dengan memaksimalkan bimbingan konseling yang diberikan kepada siswa. Selain itu, mempertimbangkan daya kreativitas siswa yang berbeda satu sama lain, bimbingan individu adalah bimbingan yang peneliti rasa tepat untuk diterapkan dalam penelitian ini.

Manfaat hasil penelitian secara teoritis, diharapkan akan bermanfaat sebagai acuan dalam memperkaya teori dalam rangka peningkatan motivasi dan kreativitas pengembangan diri siswa. Sedangkan secara praktis penelitian ini diharapkan bermanfaat: 1) bagi sekolah, dalam rangka meningkatkan prestasi belajar khususnya dalam mengikuti proses pembelajaran dikelas; 2) Bagi guru-guru pengajar, hasil penelitian ini diharapkan dapat dijadikan acuan dalam menyusun strategi pembelajaran untuk dapat meningkatkan prestasi belajar siswa; 3) Bagi sekolah, hasil penelitian ini dapat meningkatkan kualitas pendidikan di sekolah, dapat digunakan sebagai bahan kajian dalam upaya peningkatan mutu pendidikan di sekolah; 4) Bagi siswa, dapat memberikan pengalaman mengenal metode bimbingan yang bermanfaat untuk mengembangkan prestasi belajar.

Bimbingan individu merupakan bantuan kepada seluruh siswa yang dilakukan secara berkesinambungan supaya mereka dapat memahami dirinya (potensi dan tugas-tugas perkembangannya), dan memahami lingkungan sehingga mereka mampu mengarahkan diri, menyesuaikan diri secara dinamis dan konstruktif terhadap norma yang berlaku atau tuntutan lembaga pendidikan, keluarga, masyarakat dan lingkungan kerja yang akan dimasukinya kelak (Syamsu Yusuf dan Juntika Nurihsan, 2009: 13).

Secara umum, proses konseling terdiri dari tiga tahapan yaitu: Tahap awal (tahap mendefinisikan masalah). Tahap ini terjadi dimulai sejak siswa menemui konselor hingga berjalan sampai konselor dan siswa menemukan masalah siswa. Pada tahap ini beberapa hal yang perlu dilakukan, diantaranya: (a) membangun hubungan konseling yang melibatkan siswa (raport) kunci keberhasilan membangun hubungan terletak pada terpenuhinya asasasas bimbingan dan konseling terutama asas kerahasiaan, kesukarelaan, keterbukaan dan 
kegiatan, (b) memperjelas dan mendifinisikan masalah. Jika hubungan konseling sudah terjalin dengan baik dan siswa telah melibatkan diri maka konselor harus dapat membantu memperjelas masalah siswa, (c) membuat penaksiran dan penjajagan. Konselor berusaha menjajagi atau menafsir kemungkinan masalah dan merancang bantuan yang mungkin dilakukan, yaitu dengan membangkitkan semua potensi siswa dan menentukan berbagai alternatif yang sesuai bagi antisipasi masalah, Menegosiasikan kontrak. Membangun perjanjian antara konselor dengan siswa: (1) kontrak waktu, yaitu berapa lama waktu pertemuan yang diinginkan oleh siswa dan konselor tidak berkeberatan; (2) kontrak tugas, yaitu berbagai tugas antara konselor dan siswa; dan (3) kontrak kerjasama dalam proses konseling, yaitu terbinanya peran dan tanggung jawab bersama antara konselor dan konseling dalam seluruh rangkaian kegiatan konseling. Tahap inti (tahap kerja), setelah tahap awal dilaksanakan dengan baik, proses konseling selanjutnya adalah memasuki tahap ini atau tahap kerja. Pada tahap ini terdapat beberapa hal yang harus dilakukan, diantaranya: (a) menjelajahi dan mengeksplorasi masalah siswa lebih dalam. Penjelajahan masalah dimaksudkan agar siswa mempunyai perspektif dan alternatif baru terhadap masalah yang sedang dialaminya, (b) konselor melakukan reassesment (penilaian kembali). bersama-sama siswa meninjau kembali permasalahan yang dihadapi siswa, (c) Menjaga agar hubungan konseling tetap terpelihara.

Sementara itu, terkait dengan Prestasi adalah hasil yang telah dicapai seseorang dalam melakukan kegiatan. Gagne menyatakan bahwa prestasi belajar dibedakan menjadi lima aspek, yaitu : kemampuan intelektual, strategi kognitif, informasi verbal, sikap dan keterampilan. Menurut Bloom dalam Suharsimi Arikunto bahwa hasil belajar dibedakan menjadi tiga aspek yaitu kognitif, afektif dan psikomotorik. Prestasi merupakan kecakapan atau hasil kongkrit yang dapat dicapai pada saat atau periode tertentu. Berdasarkan pendapat tersebut, prestasi dalam penelitian ini adalah hasil yang telah dicapai siswa dalam proses pembelajaran. Sedangkan prestasi belajar itu sendiri diperoleh melalui proses pendidikan. Potensi pendidikan seseorang akan berbeda dengan potensi pendidikan orang lain.

Berdasarkan landasan teori di atas, dapat disampaikan hipotesis dalam penelitian ini sebagai berikut: Jika bimbingan konseling dapat diupayakan secara maksimal dalam pembelajaran maka akan dapat meningkatkan Prestasi Belajar siswa Kelas VIII A Semester I Tahun Pelajaran 2017/2018 SMP Negeri 2 Kerambiatan.

\section{Metode}

Tempat pelaksanaan penelitian ini adalah di SMP Negeri 2 Kerambitan. Penelitian dilaksanakan mengikuti siklus. Rancangannya sebagai berikut:

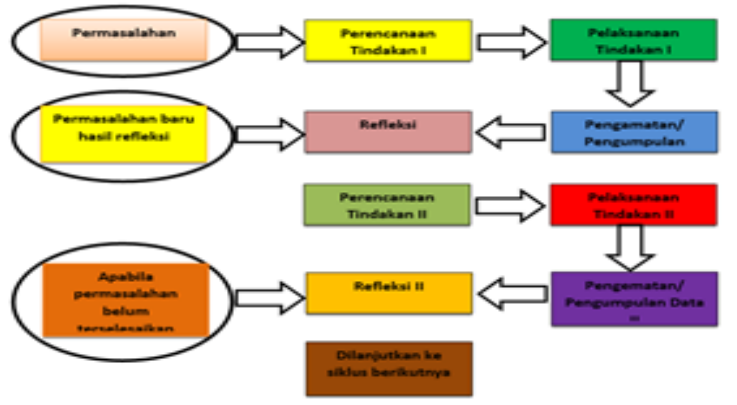

Gambar 1. Alur Penelitian Tindakan Kelas (dalam Suharsimi Arikunto, 2006)

Subjek pada penelitian ini adalah semua siswa kelas VIII A Semester I Tahun Pelajaran 2017/2018 SMP Negeri 2 Kerambiatan. Sementara itu, Objek penelitian ini adalah peningkatan prestasi belajar Bahasa Indonesia siswa kelas VIII A Semester I Tahun 
Pelajaran 2017/2018. Jadwal dari penelitian tindakan kelas ini dari bulan Juli s/d bulan November 2017 Tahun Pelajaran 2017/2018.

Untuk mengumpulkan data pada penelitian ini digunakan metode observasi dan kuisioner kepada siswa, kemudian Metode yang digunakan adalah metode deskriptif. Untuk data kuantitatif dianalisis dengan mencari mean, median, modus, membuat interval kelas dan melakukan penyajian dalam bentuk tabel dan grafik

\section{Hasil dan Pembahasan}

\section{Perencanaan awal}

Diketahui total subjek penelitian sebanyak 24 siswa, nilai rata-rata Prestasi Belajar Bahasa Indonesia yang diperoleh adalah 69,33. Apabila rata-rata tersebut dikonversikan maka rata-rata tersebut hanya mencapai tingkatan C (Cukup Baik). Persentase ketuntasan siswa hanya mencapai $45 \%$. Paparan di atas menunjukan sebagian besar siswa masih memerlukan bimbingan konseling untuk meningkatkan motivasi dan kreativitasnya

\section{Deskripsi Siklus I}

a. Rencana Tindakan I

Setelah melihat data awal pelaksanaan kegiatan awal di atas maka diterapkanlah bimbingan individu dalam meningkatkan motivasi dan kreativitas pengembangan diri. Perencanaan dimulai dari siklus I dilakukan mengikuti pendapat ahli pendidikan yaitu memperbaiki semua kelemahan pada Kegiatan Awal sebelumnya

b. Pelaksanaan Tindakan I
1) Membangun hubungan konseling yang melibatkan siswa
2) Memperjelas dan mendifinisikan masalah
3) Membuat penaksiran dan penjajagan
4) Membangun perjanjian antara guru dengan siswa
5) Menjelajahi dan mengeksplorasi masalah siswa lebih dalam
6) Melakukan peninjauan kembali bersama siswa
7) Menjaga agar hubungan konseling tetap terpelihara

c. Observasi

Pada siklus I, nilai rata-rata Prestasi belajar Bahasa Indonesia meningkat menjadi 74. Apabila rata-rata tersebut dikonversikan maka rata-rata tersebut telah mencapai tingkatan $\mathrm{C}$ (Cukup Baik). Persentase ketuntasan siswa juga mengalami peningkatan menjadi $63 \%$

d. Refleksi

Berdasarkan data yang telah dikumpulkan, analisis kuantitatif motivasi adalah sebagai berikut :

1. Rata-rata (mean) dihitung dengan: $\frac{\text { Jumlah nillai }}{\text { Jumlah siswa }}=\frac{1776}{24}=74$

2. Median (titik tengahnya) adalah: 74

3. Modus adalah: 80

4. Untuk persiapan penyajian dalam bentuk grafik maka hal-hal berikut dihitung terlebih dahulu.

1) Banyak kelas $(\mathrm{K})=1+3,3 \times \log (\mathrm{N})$

$$
\begin{aligned}
& =1+3,3 \times \log 24 \\
& =1+3,3 \times 1,38 \\
& =1+4,6=5,6=6
\end{aligned}
$$

2) Rentang kelas $(r)=$ skor maksimum - skor minimum

$$
=91-61=30
$$

3) Panjang kelas interval (i) $=\frac{r}{K}=5$ 
Tabel 1. Data Kelas Interval Siklus II

\begin{tabular}{ccccc}
\hline No & Interval & $\begin{array}{c}\text { Nilai } \\
\text { Tengah }\end{array}$ & Frekuensi Absolut & Frekuensi Relatif \\
\hline 1 & $61-65$ & 63 & 5 & $21 \%$ \\
2 & $66-70$ & 68 & 6 & $25 \%$ \\
3 & $71-75$ & 73 & 2 & $8 \%$ \\
4 & $76-80$ & 78 & 4 & $17 \%$ \\
5 & $81-85$ & 83 & 6 & $25 \%$ \\
6 & $86-91$ & 88 & 1 & $4 \%$ \\
\hline
\end{tabular}

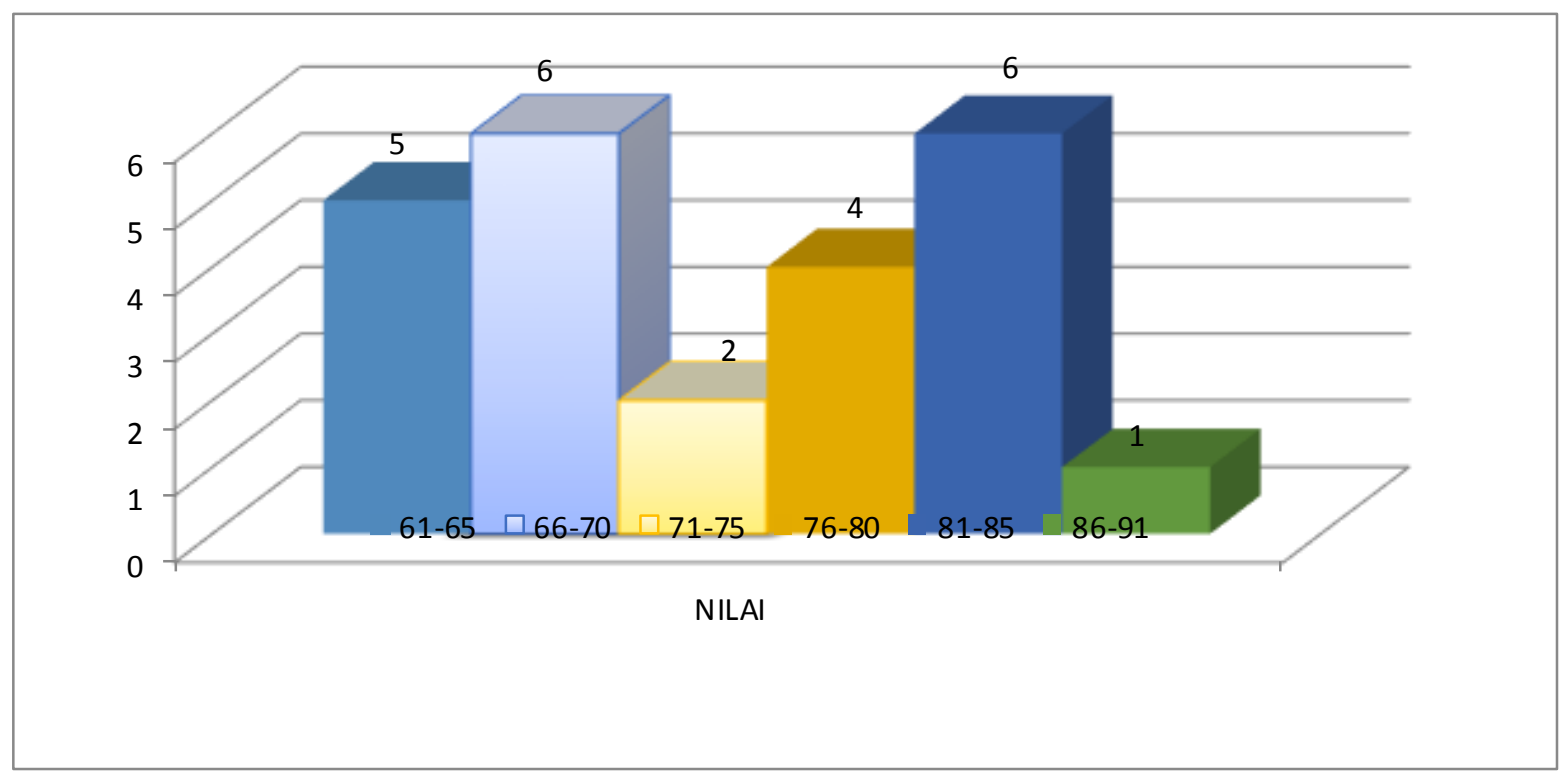

Gambar 2. Histogram Perstasi Belajar Siswa Kelas

VIII A SMP Negeri 2 Kerambitan

Penilaian yang dapat disampaikan terhadap seluruh kegiatan tindakan Siklus I ini bahwa indikator yang dituntut dalam penelitian ini masih belum tercapai. Hasil yang diperoleh pada siklus I ini menunjukkan bahwa penelitian ini perlu dilanjutkan lagi ke siklus berikutnya

\section{Deskripsi Siklus II}

a. Rencana Tindakan II

Semua kelemahan yang sudah dipaparkan pada siklus I merupakan acuan untuk membuat perencanaan pada siklus II ini.

b. Pelaksanaan Tindakan II

Langkah dalam pelakasnaannya sesuai apa yang telah dilaksanakan pada siklus I dan diberi penekanan

c. Observasi

Nilai rata-rata Prestasi Belajar siswa pada siklus II meningkat menjadi 81. Persentase ketuntasan siswa juga mengalami peningkatan menjadi 96\% karena 23 siswa diantaranya memperoleh nilai sesuai dengan KKM.

d. Refleksi 
Berdasarkan data yang telah dikumpulkan, Selanjutnya diberikan analisis kuantitatifnya mengingat data yang diperoleh adalah dalam bentuk angka sebagai berikut :

1. Rata-rata (mean) dihitung dengan: $\frac{\text { Jumlah nillai }}{\text { Jumlah siswa }}=\frac{1921}{24}=81$

2. Median adalah: 80

3. Modus adalah: 80

4. Untuk persiapan penyajian dalam bentuk grafik maka hal-hal berikut dihitung terlebih dahulu.
1. Banyak kelas $(K)=1+3,3 \times \log (N)$
$=1+3,3 \times \log 24$
$=1+3,3 \times 1,38$
$=1+4,6=5,6=6$

2. Rentang kelas $(r)=$ skor maksimum - skor minimum

$$
=90-61=20
$$

3. Panjang kelas interval (i) $=\frac{r}{K}=5$

Tabel 2. Data Kelas Interval Siklus II

\begin{tabular}{|c|c|c|c|c|}
\hline NO & Interval & Nilai Tengah & Frekuensi Absolut & Frekuensi Relatif \\
\hline 1 & $61-65$ & 63 & 1 & $4 \%$ \\
\hline 2 & $66-70$ & 68 & 2 & $8 \%$ \\
\hline 3 & $71-75$ & 73 & 3 & $13 \%$ \\
\hline 4 & $76-80$ & 78 & 7 & $29 \%$ \\
\hline 5 & $81-85$ & 83 & 8 & $33 \%$ \\
\hline 6 & $86-91$ & 88 & 3 & $13 \%$ \\
\hline \multicolumn{3}{|c|}{ TOTAL } & 24 & $100 \%$ \\
\hline
\end{tabular}

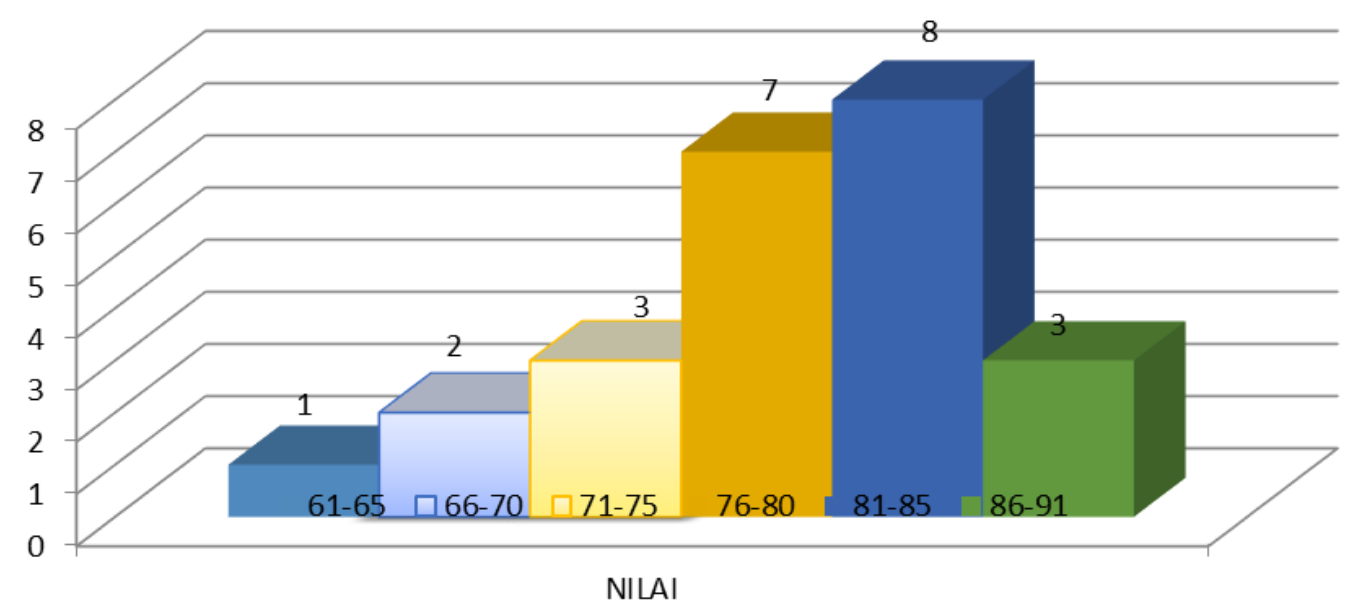

Gambar 3. Histogram Prestasi Belajar Siswa Kelas VIII A SMP Negeri 2 Kerambitan 
Masalah motivasi yang dimiliki siswa yang tampak pada data awal adalah dari 24 siswa, nilai rata-rata perolehan mereka adalah 69,33. Persentase ketuntasan siswa hanya mencapai $45 \%$. Setelah diberikan tindakan dengan melaksanakan Bimbingan Konseling kepada siswa, terjadi peningkatan pada Prestasi Belajar siswa. Pada siklus I, nilai rata-rata Prestasi Belajar siswa meningkat menjadi 74. Persentase ketuntasan siswa juga mengalami peningkatan menjadi $63 \%$. Meskipun telah terjadi peningkatan nilai pada siklus I namun nilai tersebut belum cukup untuk memenuhi tuntutan indikator dalam penelitian ini. Hasil yang diperoleh pada siklus I ini menunjukkan bahwa penelitian ini perlu dilanjutkan lagi ke siklus berikutnya

Pada siklus II, dengan perencanaan, dan pelaksanaan yang lebih matang, pelaksanaan bimbingan ditekankan lebih mendalam kepada semua siswa. Dari hasil tersebut, hampir seluruh siswa mengalami peningkatan Prestasi Belajar. Peningkatan tersebut disinyalir lebih baik dibandingkan dengan hasil pada siklus I. Hal ini dapat dilihat dari hasil yang diperoleh siswa, yaitu pada penilaian Prestasi Belajar hasil yang diperoleh nilai rata-rata siswa meningkat menjadi 81 . Persentase ketuntasan siswa juga mengalami peningkatan menjadi $96 \%$.

Hasil penelitian pada siklus II menunjukkan bahwa pemberian tindakan dengan melaksanakan layanan Bimbinga Kponseling dapat meningkatkan Prestasi Belajar Bahasa Indonesia siswa secara signifikan. Dan hal ini dapat menjawab semua permasalahan yang ada.

\section{Simpulan dan Saran}

\section{Simpulan}

Simpulan yang diperoleh pada Penelitian Tindakan Kelas (PTK) ini adalah Bimbingan Konseling dapat meningkatkan Prestasi Belajar Siswa Kelas VIII A Semester I Tahun Pelajaran 2017/2018 SMP Negeri 1 Kerambitan.

\section{Saran}

Berdasarkan kesimpulan di atas dapat disampikan saran yaitu 1) Bagi guru-guru BK yang ingin menggunakan hasil penelitian ini dapat menerapkan temuan yang telah diperoleh untuk membantu meningkatkan Prestasi Belajar siswa dengan mengoptimalkan cara-cara bimbingan Konseling; 2) Bagi peneliti yang ingin mendalami model yang peneliti teliti dapat mencoba penelitian yang sama dengan mengkaji bagian-bagian yang belum sempat diteliti; 3) Bagi sekolah, pengembangan layanan BK perlu sesering dilakukan, dan diharapkan lebih sering melakukan koordinasi mengenai permasalahan siswa di kelas

\section{Daftar Pustaka}

A Hallen, Bimbingan dan Konseling, Jakarta : Ciputat Pers : 2002.

Sofyan S. Willis, Konseling Individual Teori dan Praktek, Bandung : Alfabeta, 2007.

Arikunto, Suharsimi; Suhardjono; Supardi. 2006. Penelitian Tindakan Kelas. Jakarta: PT Bumi Aksara. 